\title{
The Performance of Marine Insurance Firms in Nigeria: An Augmented SWOT Analysis
}

\author{
Donatus Eberechukwu Onwuegbuchunam ${ }^{1}$, Chinemerem Igboanusi ${ }^{2}$, Innocent Chuka Ogwude ${ }^{2}$ \\ ${ }^{1}$ Department of Maritime Management Technology, Federal University of Technology Owerri, Nigeria \\ ${ }^{2}$ Department of Transport Management Technology, Federal University of Technology Owerri, Nigeria
}

Email address:

donafutow@yahoo.com (D. E. Onwuegbuchunam)

\section{To cite this article:}

Donatus Eberechukwu Onwuegbuchunam, Chinemerem Igboanusi, Innocent Chuka Ogwude. The Performance of Marine Insurance Firms in Nigeria: An Augmented SWOT Analysis. International Journal of Transportation Engineering and Technology.

Vol. 3, No. 4, 2017, pp. 83-90. doi: 10.11648/j.ijtet.20170304.16

Received: August 3, 2017; Accepted: August 28, 2017; Published: December 27, 2017

\begin{abstract}
The performance of Nigeria insurance industry has been ranked below global standards and which ranking has implications on risk management in the maritime shipping sector. In this paper, the performance and operating environment of a sample of insurance firms (with marine risk portfolios) were empirically examined. Secondary data on earned premium income, indemnity paid, management expenses and total expenses representing performance indices of these firms over a period from 1974-2013 were collected for analysis of their operational performance. Qualitative data were also extracted from existing literature for Strengths, Weakness, Opportunities and Threats (SWOT) analysis to determine the attributes of operating environment of the insurance firms. An Analysis of Variance (ANOVA) model tests on the performance indices showed that the insurance firms earned more premium than indemnity paid out during the study period. Their management expenses however, exceeded amount of indemnity paid. In terms of challenges facing the firms, the SWOT analysis revealed prevalence of poor quality service delivery to insurance customers, customer distrust, inadequate technical manpower and unfavourable macro-economic environment. Prospects for growth of the industry were found favourable due to introduction of local content policy/cabotage shipping Acts and upgraded risk management framework. The paper recommends that more specific policy interventions be directed at complete removal of impediments in the operating environment of marine insurance firms since their performance outcome has implications on viability of shipping and related maritime businesses.
\end{abstract}

Keywords: Marine Insurance, SWOT Model, Premium, Indemnity, Performance Indices

\section{Introduction}

Marine insurance service drives international shipping which according to documented evidence, caters for about $90 \%$ of World trade. Increasing world trade and associated shipping services have necessitated expansion in risk coverage offered by marine insurance industry. For example, marine risk covers are available for Artic shipping, Aquaculture farming, carbon shipping, offshore energy, cyber-attacks and maritime terrorism etc. Despite the significance of marine insurance to the shipping sector and generally the economy, the industry performance is far from being optimal [1]. Various studies articulate the problems besetting global marine insurance industry. Some notable factors inhibiting uptake of marine insurance include lack access to foreign marine insurance packages, poor public awareness of products available, lack of trust on insurance firms to deliver, inadequate skilled manpower, ineffective government control and poor stakeholder organization in the sector [2]. Other studies have found financial performance of the industry to be dependent on variables as GDP, Genderrelated Development Index (GDI) [3] and economic development of a nation [4].

In Nigeria, non-life and life insurance products ranked 57th and 63rd positions respectively in the year 2013 [1]. The observed performance by IMF falls below expectation given reforms efforts undertaken by the federal government of Nigeria. These reforms include, pruning down inefficient firms through financial recapitalization which reduced prereform number of firms from 104 to 49 [5] and strengthening of regulatory environment of the sector. The sub-optimal 
performance of the insurance industry which has persisted despite the reforms has provided the impetus to this research work in which augmented SWOT analysis was carried out to examine prospects and challenges of the Nigeria insurance industry. In realisation of the major aim of this research, the following objectives are addressed:

Objectives of Study

1. To identify the significant factors affecting environment marine insurance firms.

2. To evaluate the operational performance indices of marine insurance firms.

3. To determine the trends in the performance indices of marine insurance firms.

The scope of this research work will be limited to analysis of underwriting activities of Nigeria insurance firms (with marine risks portfolios) for the years from 1974-2013. The performance indices and operating environment of marine insurance firms would be empirically evaluated to determine their overall performance. The rest of the paper is structured as follows: section 2 presents a background of Nigeria insurance industry and review of their operating environment based on SWOT (an acronym for Strengths, Weaknesses, Opportunities and Threats) framework. The methodology of the paper is discussed in section 3. Analysis of data for the study and discussion of findings are done in section 4 . Section 5 concludes the study.

\section{Conceptual Review}

\subsection{Profile of Nigeria Insurance Sector}

The enormous potential of the insurance business has remained untapped in Nigeria [6]. According to the National Insurance Commission (NAICOM), insurance penetration recorded an increase from $4.3 \%$ in 2006 to around 0.5 per cent in 2008 and dropped to 0.3 per cent in 2014; which is lower than the African average of 2.8 per cent. In addition, total capitalization of the industry grew from N200 billion (US\$1.36 billion) in 2006 to N550 billion (US\$3.74 billion) in 2008, while gross premium also improved from N94 billion (US $\$ 639.4 \mathrm{~m}$ ) to about N180 billion (US\$1.23 billion) [7]. This growth however, is insignificant considering the target of N60 trillion (US $\$ 400.81$ billion) by 2020 set by the NAICOM [8]. Low capital formation, poor implementation of requisite policies and environmental constraints are considered to negatively impact on growth potentials of Nigeria insurance industry.

A number of policy measures have been introduced by NAICOM. These measures (e.g. Market Development and Restructuring Initiative [MDRI]) were aimed at strengthening the Nigeria insurance market, creating awareness for greater insurance penetration and hence improve volume of insurance premium, density and contribution to GDP [9] However, between years 2012 and 2013, gross premium on marine insurance dipped following import restriction policy of the federal government and low profile of economic activities [10]. The abysmal performance of the sector demands that continuous analysis be carried out in order to guide requisite policy interventions. Thus, analysis of a Strengths, Weaknesses, Opportunities and Threats (SWOT) of marine insurance firms given the challenges in their operating environment will provide basis for policy improvements in the sector

\subsection{SWOT Analysis Theory}

SWOT analysis or SWOT matrix is an acronym for strengths, weaknesses, opportunities, and threats. It is a structured planning method that evaluates those four elements of a project or business venture. SWOT analysis is a business analysis technique that an organization can perform for each of its products, services, and markets when deciding on the best way to achieve future growth. The process involves identifying the strengths and weaknesses of the organization, and opportunities and threats present in the market that it operates in [11]. In subsequent section, we apply the techniques of SWOT model to carry out a qualitative review of the potentials and challenges in the operating environment of the Nigeria insurance industry.

\subsection{SWOT Review of the Nigeria Insurance Sector}

\subsubsection{Strengths}

1. Given the size of its economy, Nigeria with a GDP of \$514.97bn in 2013, \$568.51bn in 2014 and \$481.07bn in 2015 , is rated as the country with the largest economy in Africa. According to IMF's World economic outlook projections, Nigeria is expected to grow at a faster rate than the average emerging market and developing economies growth of $5.3 \%$ and the average growth rate in Sub-Saharan Africa of 5.95\%. Following the GDP rebasing policy, insurance now contributes significantly to GDP (from a quarterly contribution of $0.15 \%$ to quarterly contribution of $0.45 \%$ after the GDP rebasing policy according to some documented evidence).

2. Consequent upon the recapitalization policy, NAICON has upgraded its regulatory requirements, including a voluntary code on corporate governance, operational guidelines, risk management framework, KYC (Know Your Client) and AML/CFT (Anti-Money Laundering/Combating the Financing of Terrorism) requirements, and the adoption of IFRS (International Financial Reporting Standard). These initiatives have significantly improved the regulatory environment for the industry [1].

3. There are now 1,227 marine cargo vessels owned by Nigerians; according to reference [12]. This figure is a measure of potential local demand for marine insurance products. If local shipping companies patronize local marine insurers, this will boost profitability in the marine insurance industry.

4. The local content policy aims to ensure that at least $60 \%$ of marine assets are in the hands of Nigerians by the years 2015. For example, the Nigerian Content Development and Monitoring Board's marine vessel 
utilization scheme encourages construction of vessels in Nigerian yards, promotes ownership of marine vessels by Nigerian nationals, stimulate flagging and registration of vessels in Nigeria and manning of marine vessels by Nigerians [13].

5. "A total of 600 vessels are operating in Oil and Gas sector in Nigeria and only 10 per cent belongs to Nigerians as at 2015,". It is estimated that between three to seven trillions of naira could be generated annually through the maritime industry if its potentials are fully harnessed [14]. This projection has positive implications for the marine insurance industry.

\subsubsection{Weaknesses}

Poor Customer Satisfaction: Most insurance companies in Nigeria are grappling with problem of satisfying their customers in terms of product offerings, quality of services and sophistication of products offered [15]. While customer service is clearly important for winning new customers and retaining existing ones, Nigerian insurance industry struggles to achieve an acceptable level of customer satisfaction. In the light of slow industry growth, many insurance companies have pursued mergers and acquisition to increase market share and achieve economies of scale. While this strategy might be functional, the optimal strategy is keeping existing customers and attracting new ones [16].

Lack of public trust in Insurance Companies: Poor patronage and performance stem from the poor attitude of the insurers in claims payment. The tradition of defaulting in claims translated to some form of bad publicity for the industry and consequently, confidence in the industry eroded significantly. Policy documents still carry clauses that breeds distrust with customers [17].

Lack of technical manpower: poor technical skills and knowledge gaps are major factors accounting for foreign domination and monopoly of the marine insurance sector [18].

Poor Enforcement: Nigerian insurance industry is challenged in enforcement of rules on compulsory insurance. It is common to have fake insurance papers presented as genuine ones especially on Marine and motor insurance assessment.

\subsubsection{Opportunities}

The National Marine Insurance Bureau has been established to take charge of and collect insurance levies on crude or gas cargo exports. The thrust of this policy is to check capital flights (in billions of US dollars) which Nigeria loses to foreign insurance companies dominating the marine insurance sector [18].

The sector has been strengthened for greater efficiency through recapitalization policy. Substantial increase in the minimum capital requirements in 2007 led to a reduction in the number of insurers from 104 to 60 in 2008. Further market consolidation, albeit at a lower scale, is expected as a result of regulation requiring banks to divest their nonbanking activities including insurance [1].

The introduction of the local content policy of the oil and gas industry represents significant boost to all allied sectors to the oil and gas sector including marine insurance. The implementation of the Local Content Act, in accordance with Insurance Act of 2003, the National Insurance Act of 1997, and issuance of guidelines for oil and gas business in Nigeria, 100 per cent, 70 per cent and 40 per cent of all life, non-life and marine insurance risks respectively in the Nigerian oil and gas industry are to be controlled by Nigeria insurers [19].

Institution of compulsory "Cost Insurance and Freight" (CIF) in the oil and gas shipping and export businesses done in Nigeria. The application of Cost Insurance and Freight terms in Nigeria's export contracts provides revenue making opportunities for Nigerian Insurers.

\subsubsection{Threats}

\section{Poor Regulatory Framework}

According to reference paper [16], the regulators of Nigerian insurance industry weakly enforce policies. According to the paper, this is evident in the near absence of operating standards and lack of administration, supervision and control of marine insurance businesses in the sector. Consequently, to date no concrete policy statement is issued on the companies that have not complied with operating requirements in the industry [16].

2. Unfavorable Macroeconomic Environment

A stable macroeconomic environment promotes the savings necessary to finance investments - a precondition for achieving viable insurance industry and sustainable economic growth. Insurance companies are sensitive to economic fundamentals. Nigeria's macroeconomic policies over the last decade have been characterized by periodic financial indiscipline, leading to volatile and generally high inflation, large exchange rate swings, and negative real interest rates for extended periods. Such economic conditions might increase insurance premium or deter the ability of insurers to pay claims [16].

3. Unreliable Judicial system

Litigation in our Courts in Nigeria today is known to be long-winding and it is not uncommon for cases to remain in courts of first instance for 5years. The delays experienced in litigation can be most damaging where commercial disputes are involved. This is more so in maritime insurance disputes litigation where parties to litigation are more than often local and international [20].

From the foregoing literature review, the factors constituting strengths, weaknesses, opportunities and threats in the operating environment of marine insurance firms in Nigeria are articulated. These factors will be considered as inputs in the construction of SWOT matrix in the data presentation section. The methodology of this study is discussed in the subsequent section.

\section{Methodology}

A survey research approach was adopted to collect data for the performance assessment of insurance firms which offer marine risk portfolios in the Nigeria's maritime sector. The secondary data analysed in the study were collected from 
records of insurance firms offering marine risk policy which covered their operational activities from years 1974 to 2013. These data were augmented and validated with other records from various issues of Central Bank of Nigeria statistical bulletins, annual reports of Nigerian Insurance Commission's and Nigerian Insurance Association. The data contained the following; amount of premium earned by these companies, indemnity paid out, management expenses and total expenses incurred from their operations. For our research purposes, these financial indicators are defined as indices of performance of these firms.

The performance indices and environment of marine insurance firms in Nigeria were analysed using statistical and SWOT models respectively. The research process adopted is captured in the concept diagram in figure 1. Based on the findings from existing literature, we identified micro and macro-economic factors (grouped as SWOT items) affecting the performance of insurance firms in Nigeria. Thus, as depicted in figure 1 and in consistent with existing research, these external influences are postulated as impacting on overall performance of the insurance industry.

To address the research hypotheses implied in the objectives governing this study, a statistical model, Analysis of Variance (ANOVA) was applied to determine if the mean values of performance indices of the firms were significantly different zero. Pairwise comparisons of the indices after ANOVA were also done to determine which variables were significantly different from each other. This helped to determine the profitability or otherwise of the firms during the study period, see section 3.1 for the discussion of ANOVA model. Furthermore, trend analysis of the performance indices enabled the assessment of the firms' future profile. SWOT analysis was subsequently done to examine the prospects (Strengths \& Opportunities) and challenges (Weaknesses \& Threats) in the operating environment of the firms and which results complemented the statistical findings. In the subsequent sections, we discuss the findings from the data analysis and the implications for policy.

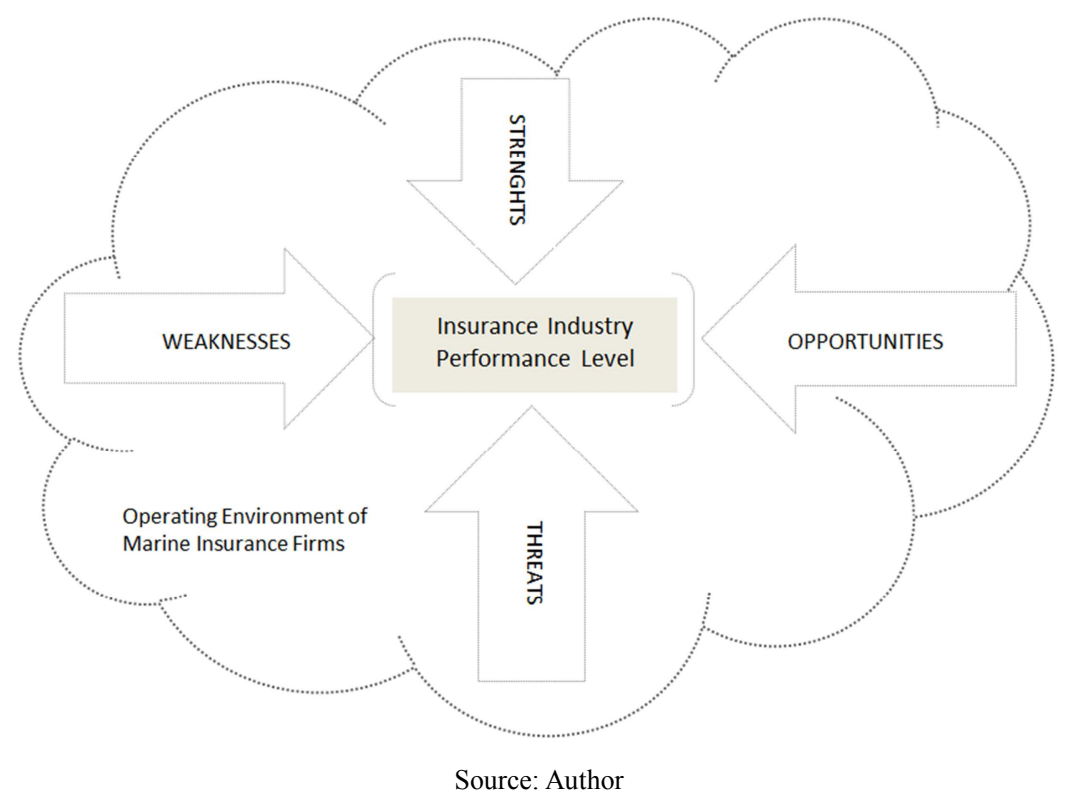

Figure 1. Conceptual SWOT model of the research process.

\subsection{Anova Model}

Analysis of variance (ANOVA) is a method for testing the hypothesis that there is no difference between several population means (usually at least three) when there is only one qualitative variable which denotes the groups and only one measurement variable (quantitative).

Mathematically, ANOVA Model can be formulated as

$$
X_{i j}=\mu+\alpha_{i}+e_{i j} ; i=1,2, \ldots, k ; j=1,2, \ldots, n .
$$

Where: $X_{i j}=$ the measurement in the $(i j)$ th cell

$\mu=$ grand mean

$\alpha=$ effect of the ith treatment

$e_{i j}=$ the error associated with $X_{i j}$. Assumptions: $e_{i j} \sim N\left(0, \sigma^{2}\right)$ $\sum_{i} \alpha_{i}=0$

\subsection{Hypothesis}

$$
H_{0}: \alpha_{1}=\alpha_{2}=\alpha_{3}
$$

$H_{A}:$ at least $\alpha_{1} \neq 0$

$x_{i j}=$ performance indices.

$i=1,2,3$ represents premium, indemnity and management expenses

$j=1,2,3, \ldots, 40$ represents year

\section{Presentation of Data and Analyses}

The secondary data on performance indices of firm for 
various years are shown in table 1. A truncated version of data is presented for sake of brevity and space. However, the descriptive statistics of the complete data set, which our discussion is based on, are shown in table 2 .

Table 1. Performance Indices (in million naira) of Marine Insurance Firms in Nigeria.

\begin{tabular}{lllll}
\hline Year & Premium & Indemnity & Mgt. Exp & Total Exp \\
\hline 1974 & 3.153 & 1.212 & 1.046 & 133.411 \\
1975 & 5.030 & 1.662 & 2.764 & 187.150 \\
1976 & 4.403 & 1.706 & 3.158 & 194.938 \\
1977 & 21.224 & 3.820 & 5.223 & 111.313 \\
1978 & 23.661 & 6.377 & 6.458 & 135.942 \\
1979 & 16.145 & 8.989 & 8.342 & $1,077.272$ \\
“ & “ & “ & “ & “ \\
“ & “ & “ & “ & “ \\
2007 & $11,255.655$ & $1,904.230$ & $5,879.258$ & $1,931.827$ \\
2008 & $17,231.092$ & $3,185.000$ & $6,141.113$ & $3,220.251$ \\
2009 & $16,727.575$ & $4,556.600$ & $7,428.493$ & $4,602.673$ \\
2010 & $20,097.368$ & $2,965.170$ & $5,028.569$ & $2,979.823$ \\
2011 & $23,400.508$ & $2,889.584$ & $5,252.347$ & $2,959.064$ \\
2012 & $26,077.150$ & $6,815.302$ & $6,888.267$ & $6,949.256$ \\
2013 & $14,726.610$ & $8,009.112$ & $8,036.311$ & $8,189.995$ \\
\hline
\end{tabular}

Source: Author's compilation based on field work

In table 2, we present descriptive statistics of performance indices of the firms for the period between the years 1974 to 2013. Important variables examined were: premium earned by these firms, amount of indemnity provided, management expenses (Mgt_Exp) and total expenditure (Tot_Exp) incurred in the course of their operation. Thus, for the period of study, it is noted that these firms garnered an average of \#5.943 billion naira in earned premium. The amount of indemnity provided to policy holders was valued at \#1.027 billion naira. However, managerial expenses and total expenditure for the industry amounted to \#1.594 and \#2.058 billion naira respectively. Based on table 2, it is apparent that the industry made profit as premium earned exceeded expenses made.

Table 2. Descriptive Statistics: Indices of Performance of the Insurance Firms (in million naira).

\begin{tabular}{lllll}
\hline Variable & Mean & Std. Dev. & Min & Max \\
\hline Premium & 5,943 & 8,111 & -2.897 & 26,077 \\
Indemnity & 1,027 & 1,885 & -0.010 & 8,009 \\
Mgt_Exp & 1,594 & 2,475 & 1.046 & 8,036 \\
Tot_Exp & 2,058 & 2,290 & 111.31 & 8,190 \\
\hline
\end{tabular}

Source: Author's own computation based on field work

In terms of prospects, trends in the performance indices however revealed volatile profile of the industry; see figure 2. This volatility is also evident in table 2 where all the indices showed high standard deviations from their respective mean values. The variations appear dramatic in the case of earned premium. According to the figure, the trends have been largely positive since 1974. Thus, all indices showed increasing trend with the earned premium being more intense. As depicted in figure 2, if we ignore the sharp drop in earned premium in the years between 2012 and 2013, we can expect a positive growth in the future.

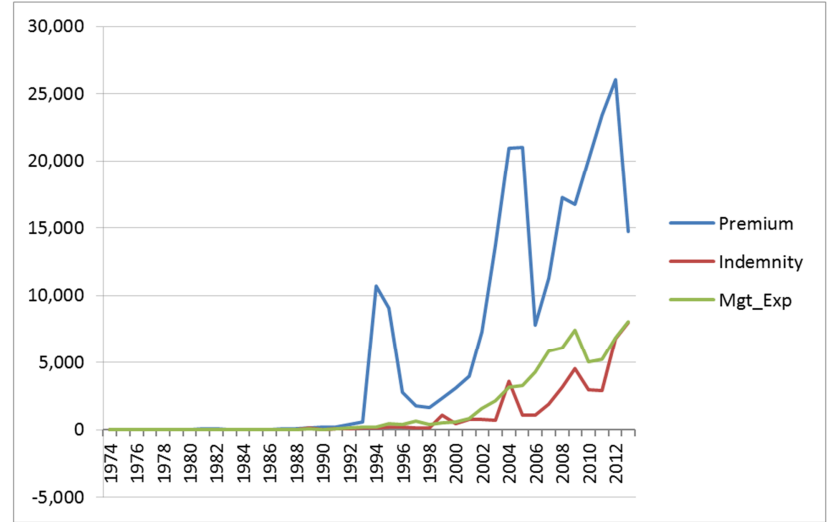

Source: Author's own elaboration

Figure 2. Trends in performance indices of insurance firms in Nigeria (1974-2013) (in billion naira).

Table 3 presents the model fitting information on analysis of variance on the performance indices. Of most interest is the value of the F statistic. This statistic has a value of 11.50 with a significant probability value of 0.000 (which is < $0.05)$. Evidence provided by the F statistic indicates that the null hypothesis of no significant variations in mean values of the performance indices can be rejected at $\alpha=0.05$ level. This result therefore justifies the pairwise comparison done in table 4 as ANOVA model does not reveal which population means differ from the others.

Table 3. Analysis of Variance (ANOVA) Model Fitting Information.

\begin{tabular}{llllll}
\hline Source & SS & df & MS & F & Prob $>$ F \\
\hline Between groups & $5.7874 \mathrm{E}+08$ & 2 & $2.8937 \mathrm{E}+08$ & 11.50 & 0.000 \\
Within groups & $2.9435 \mathrm{E}+09$ & 117 & $2.5159 \mathrm{E}+07$ & & \\
Total & $3.5223 \mathrm{E}+09$ & 119 & $2.9599 \mathrm{E}+08$ & & \\
\hline
\end{tabular}

Bartlett's test for equal variances: $\operatorname{ch} 2(2)=92.8530$ Prob $>$ chi2 $=0.000$ Source: Author's own computation

In table 4 , the means of relevant indices are compared. For the example the difference in mean values of earned premium (factor 1) and indemnity paid (factor 2) is $\# 4,916.346$ million naira. Since this difference is statistically significant, it could be concluded that the firms performed well during the study period as profit made was greater than cost of operation. Also, when the mean values of premium earned and management expenses are compared, we have a difference of $\# 4,348.893$ million naira. This also suggests that the firms covered cost of their operation and earned extra premium. This result is also statistically significant. However, when management expense (factor 3 ) is compared to indemnity paid out, a difference of \#567.4532 is realised. Although this difference is not statistically significant, the fact that management expenses exceeded value of indemnity provided to policy holders reveals a probable absence of fiscal discipline in management of financial resources in the insurance industry. In summary, it can be concluded that the industry achieved profitability as more premium income was realised than indemnity paid and managerial cost incurred. 
Table 4. Pairwise Comparison of the Firms Performance Indices (in million naira).

\begin{tabular}{llllll}
\hline & & & \multicolumn{2}{c}{$\mathbf{9 5 \%}$ Confidence Interval for Difference $^{\text {a }}$} \\
\hline (I)Factor & (J)Factor & Mean Diff ${ }^{\text {a }}$ (I-J) & Sig $^{\mathbf{a}}$. & Lower bound & Upper bound \\
\hline 1 & 2 & $4,916.346^{*}$ & 0.000 & $2,253.776$ & $7,578.917$ \\
1 & 3 & $4,348.893^{*}$ & 0.001 & $1,686.323$ & $7,011.464$ \\
3 & 2 & 567.4532 & 0.880 & $-2,095.117$ & $3,230.024$ \\
\hline
\end{tabular}

a Adjustment for multiple comparison: Tukey; *Significance at $\alpha=0.05$ level

Factors: 1: Premium; 2: Indemnity; 3: Mgt_Exp.

Source: Author's Own Computation

\section{Discussion of Findings}

The analyses done revealed positive performance outcome in the insurance sector although this outcome does not rank favourably by global standards according to IMF. It was found that the firms realised more premium than other associated expenses during the study period. However, it is worth stating that prudence should be exercised to keep management expenses well below indemnity paid out. The trend analysis of operating indices showed a positive outlook of the industry; connoting viability at least in the short term. From the SWOT analysis results (see table 5), the major strengths of the insurance sector were found to be: the ongoing strengthened regulatory environment, ongoing human capital development, relative high market share and the establishment of cabotage shipping and local content policies.

The main weaknesses can be summarized thus as: poor customer focus, poor enforcement of rules and fraudulent practices. However, opportunities have been created through market consolidation efforts. Cost Insurance \& Freight (C.I.F) now applies to oil and gas, shipping and export businesses. The major threats facing marine insurance industry are the weak Judiciary system in place and unfavourable macro-economic influences.

Table 5. SWOT Matrix Depicting Elements of the Operating Environment of Nigeria Insurance Industry.

STRENGTHS
Nigeria, Largest Economy \& Insurance Market in Africa, Projected Nig.
GDP Growth Rate $>5.95 \%$ than emerging economies [1], Insurance Sector
to Contribute Btw $0.15 \%$ to $0.45 \%$ of GDP, Strengthened Regulatory
Environment, Upgraded Regulatory Environment, Upgraded Operational
Guidelines, Upgraded Risk Management Framework, Adoption of IFRS
Reporting Standards, Building Human Capacity with knowledge and Skills
[1], Cabotage Shipping Act boosting Shipping Trade \& Marine Insurance
Markets [12], Local Content in Marine Assets to Increase to $65 \%$ [13]
OPPORTUNITIES
Establishment of National Insurance Bureau To Boost Revenue Collection
Check Capital Flights by Monopolizing Foreign Firms
Jobs Creation to Boost GDP [18]
Regulatory Efforts \& Market Consolidation Ensures Fewer but Reliable
Firms.
Institution of C. I. F in Oil \& Gas, Shipping \& Export Businesses Creating
More Opportunities

\section{STRENGTHS} to Contribute Btw $0.15 \%$ to $0.45 \%$ of GDP, Strengthened Regulatory Environment, Upgraded Regulatory Environment, Upgraded Operational 作, Upgraded Risk Management Framework, Adoption of IFRS [1], Cabotage Shipping Act boosting Shipping Trade \& Marine Insurance Markets [12], Local Content in Marine Assets to Increase to $65 \%$ [13]

Check Capital Flights by Monopolizing Foreign Firm

Jobs Creation to Boost GDP [18]

Firms.

More Opportunities
WEAKNESSES

Poor Customer Satisfaction, Lacks Multi-Channel contact Centres Interactions, Poor Product Differentiations, Lacks personalised Services, Slow Industry Growth, Lacks Public Trust, Negative Attitude of People Towards Insurance, Low patronage, Poor Attitude of Insurers in Payment of Claims [17], Policy Documents Contains Clauses that Breed Distrust, Lacks Technical Manpower, Poor Technical Skills \& Knowledge Gaps [18], Poor Enforcement of Rules in Compulsory Insurance, Fake insurance Papers in Marine \& Motor Insurance

THREATS

Poor Regulatory Frameworks

Standards Not Fully Established, Only on Legislation Documents, No Concrete Policy Statements to Enforce Compliance to Min. Capital Requirements, Unfavourable Macro-economic Environments, Nigeria Macro-economic Environment Characterised by Financial Indiscipline, high Int. Rates \& Inflation, Unreliable Judicial System, Long Winding Litigations in law courts, Delays in litigations Involving Commercial Disputes [20]

Source: Author Based on Analysis of Existing Literature.

\section{Conclusion}

Findings from this research show that despite the weakness and threats in the operating environment of the insurance industry, there is scope for improvement. It would require the combined and sustained effort of both the insurance firms and the regulatory authorities. The government through its regulatory agencies should continuously strengthen the operating environment in line with global standards. The industry should strive to improve poor service delivery by adopting global best practices and also take measures to eliminate fraudulent practices.

\section{Recommendation}

It is recommended that insurance firms should focus more on customers and create multi-channels of communication and interactions. Clauses that breed distrust among customers should be removed. Training of technical manpower in the industry (by both government and practitioners) should be a continuous process in order to be at par with international best practices. Efforts should be sustained at improving the performance of insurance firms since they infact actually service other maritime businesses.

The present research effort has evaluated performance, prospects and challenges facing the insurance industry which 
has implications on shipping and other maritime activities. Using a novel modelling framework: augmented SWOT analysis, we have combined qualitative and quantitative data in assessing the performance and operating environment of the marine insurance sector in Nigeria. This is an improvement in existing SWOT modelling which scarcely combined statistical techniques. However, we have been constrained by data in this study as we did not interview insurance consumers/customers. Doing this would have made our performance assessment complete since major stakeholder opinion would have been elicited and included. This is acknowledged as limitation and should be taken care of by future modelling effort in this direction.

\section{References}

[1] IMF (2013). International Monetary Fund Financial Sector Assessment Program Update. Washington, D. C.: International Monetary Fund. Available at:

https://www.imf.org/external/pubs/ft/scr/2013/cr13145.pdf. Accessed 6/7/16.

[2] Cheruiyot, J. R (2015) Challenges in the Uptake of Marine Cargo Insurance in Kenya. Unpublished MBA Thesis, University of Nairobi, Kenya. Available: http://erepository.uonbi.ac.ke/bitstream/handle/11295/93202/R ono. Accessed 12/06/17

[3] Akhter, W and Zia-ur-Rehman, M (2011) Financial Performance of Pakistan Insurance Industry in Global. Far East Journal of Psychology and Business, 3(2), pp. 1-7, Available:

https://www.researchgate.net/publication/227436429. Accessed 26/7/17

[4] Nwokoro I. A and Ndikom, O.B.C (2013), An Assessment of the Contribution of Marine Insurance to The Development of Insurance Markets in Nigeria. Journal of Geography and Regional Planning Vol. 5(8), pp. 212-221.

[5] Research and Market, (2009). Nigerian Insurance Report. Available: http://www.reportlink.com. Accessed 14/05/16.

[6] Okumaga, A. (2010) Nigerian Insurers Can Take Advantage of Local Content Act. Available: http://www.vanguardngr.com. Accessed 20/11/16

[7] Nse, J. (2015). Insurers Outline Strategies for Growth. The Guardian. Available: https://guardian.ng/businessservices/insurance/insurers-outline-strategies-for-growth/ Accessed 10/06/17

[8] BGL Insurance Report (2011): Promise Kept or Promise Deferred. Available:

http://resourcedat.com/wpcontent/uploads/2011/11/BGLInsurance_Report.pdf. Accessed 21/12/16.

[9] Asinobi, N. and Ojo, O. (2014). Nigerian Insurance Sector Report: Beacon Shinning Forth. Lagos: Cardinal Stone Partners. Equity Research.

[10] Onuoha, R. (2015) Nigeria: Economic Slowdown - Insurers Worry As Income from Premiums Nosedives. http://allafrica.com/stories/201510192192.html, Accessed $20 / 11 / 15$

[11] Tamplc.com (2016). The Science of TAM. TAM|UK
Research. Available: http://www.tamplc.com/research.htm. Accessed 8/7/16.

[12] FinIntell (2016). Unlocking the Potential of Maritime Industry. Available: http://www.myfinancialintelligence.com/transport/unlockingpotential-maritime-industry Accessed 7/7/16.

[13] NCMB (2014) Marine Vessel Categorization Procedure Available:

http://www.ncdmb.gov.ng/images/Guidelines/MVCP.pdf Accessed 8/7/16.

[14] Niyi, L. (2015). Nigerian Ship Owners Partner with Greeks to Acquire 40 Ships. Premium Times. Available: http://www.premiumtimesng.com/news/more-news/185879nigerian-ship-owners-partner-with-greeks-to-aquire-40ships.html. Accessed 18/05/17

[15] Osinuga, D (2016). The Challenges of the Nigerian Insurance Industry. Available: https://www.linkedin.com/pulse/challenges-nigerianinsurance-industry. Accessed on 12/02/17

[16] Ujunwa, A. and Modebe, N. (2011). Repositioning Insurance Industry for Operational Efficiency: The Nigerian Case. Journal of Applied Finance \& Banking, 1(3), pp.15-32.

[17] Obasi, N. (2010) Policies, Challenges, Reforms and Nigerian Disposition to Insurance Contracts, The Fronteira Post, 1-6.

[18] Adewale, M. (2015). New Government, New Life, New Hope: For Maritime Industry, A Better Nigeria. Nigerian Tribune. http://webcache.googleusercontent.com/ Accessed 5/07/16.

[19] Tandice-bsolution.com (2011). NAICOM to Enforce Local Content Law in Insurance Sector. Available: http://tandicebsolutions.com. Accessed 7/06/16

[20] Mondaq.com. (2016). Maritime Claims, Practices, Procedures and Enforcements-Transport-Nigeria. Available at: http://www.mondaq.com/Nigeria/ Accessed 5/7/16

\section{Biography}

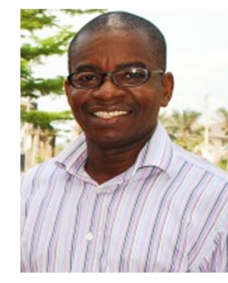

Donatus Eberechukwu Onwuegbuchunam is a Senior lecturer in the Department of Maritime Management Technology, Federal University of technology Owerri. He received his B.Tech (Second Class Honours, Upper Division) in Transport Mgt. Technology, M.Sc in Maritime Mgt. Technology and Ph.D. in Maritime Mgt. Technology from the Federal University of Technology, Owerri, Nigeria. He has at various times been Acting Head of Department of Maritime Management Technology and has published many articles in Engineering, Management, Statistics and Econometric journals.

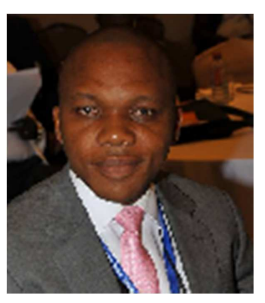

Chinemerem Igboanusi is a lecturer in the Department of Transport Management Technology, Federal University of technology Owerri (FUTO) Nigeria. He received his B.Tech in Transport Mgt. Technology from FUTO, M.Sc in Marine Transport with management from the University of New Castle, Upon Tyne, the United Kingdom. He will soon conclude his Ph.D. programme in Maritime Mgt. Technology, FUTO. He has published many articles in referred foreign Journals. 


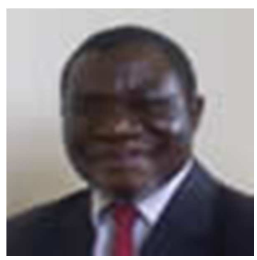

Innocent Chuka Ogwude is the foundation Professor of Transport Management at the Federal University of Technology, Owerri. He studied Economics with Statistics at the University of Ibadan (Second Class Honours Upper Division). He obtained Post Graduate Diploma (DIC) in Civil Engineering from Imperial College of Science and Technology U.K, M.Sc in Transport Engineering from the University of London. His Ph.D. degree is in Transport Economics from the University of Ibadan. Professor Ogwude has over 100 publications to his credit, in areas of Transport \& Maritime Economics, Transport Infrastructure Engineering and Management. 